\title{
Role of 8-isoprostane, Matrix Gla Protein (MGP) and Bone Morphogenetic Protein-2 (BMP-2) in Vascular Calcification in Chronic Kidney Disease
}

\author{
Wiwik Rositawati $^{1,2,}$, Syakib Bakri ${ }^{1}$, Gatot S. Lawrence ${ }^{1}$, Andi Wijaya ${ }^{1,2}$ \\ ${ }^{1}$ Postgraduate Program in Biomedics, Hasanuddin University, Jl. Perintis Kemerdekaan Km.10, Makassar, Indonesia \\ ${ }^{2}$ Prodia Clinical Laboratory, Jl. Kramat Raya No.150, Jakarta, Indonesia \\ *Corresponding author. E-mail: wiwik.rositawati@yahoo.com
}

\section{Abstract}

$\mathrm{B}$ ACKGROUND: Vascular calcification may be an important risk factor of cardiovascular disease in Chronic Kidney Disease (CKD). The pathobiology of vascular calcification in CKD is complex and involves some factors including inflammation, oxidative stress and balancing of calcification regulators. The aim of the study was to investigate the interaction between 8-isoprostane with calcification regulators such as matrix gla protein (MGP) and bone morphogenetic protein (BMP)-2 with vascular calcification in CKD.

METHODS: A cross-sectional study was performed on 63 subjects undergoing haemodialysis maintenance for more than 3 months. Abdominal aortic calcification (AAC) was measured using a lateral abdominal X-ray for calcification in abdominal aorta, which is related to severity of calcific deposits at lumbar vertebral segment (L)1-L4. Serum levels of 8-isoprostane, MGP and BMP-2 were measured by enzyme-linked immunosorbent assay method.

RESULTS: Results showed that 8-isoprostane levels were correlated with BMP-2 $(\mathrm{r}=0.266, p=0.018)$ and MGP levels $(\mathrm{r}=0.410, p=<0.001)$. MGP/BMP-2 levels ratio was correlated with AAC score $(\mathrm{r}=0.279, p=0.013)$. Subjects were then stratified into 3 groups based on AAC score: 0 , $1-6$ and $\geq 7$. The highest mean of MGP levels was in AAC score 1-6 group, and the highest mean of 8-isoprostane levels was in AAC score $\geq 7$. In the group of AAC score 0, 8-isoprostane levels were correlated with MGP levels $(\mathrm{r}=0.499, p=0.001)$ and MGP/BMP-2 levels ratio $(\mathrm{r}=0.291$, $p=0.034)$. In AAC score 1-6 group, 8-isoprostane levels were correlated with BMP-2 $(\mathrm{r}=0.661, p=0.005)$ and MGP levels $(\mathrm{r}=0.569, p=0.017)$. In AAC score $\geq 7$ group, MGP levels were positively correlated with AAC score ( $\mathrm{r}=0.608$,

\section{Abstrak}

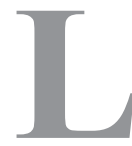

ATAR BELAKANG: Kalsifikasi vaskular merupakan faktor risiko penyakit kardiovaskular pada Penyakit Ginjal Kronik (PGK). Patobiologi kalsifikasi vaskular pada PGK sangat kompleks dan melibatkan faktor seperti inflamasi, stres oksidatif dan keseimbangan regulator kalsifikasi. Penelitian ini bertujuan untuk melihat interaksi antara 8-isoprostane dengan regulator kalsifikasi yaitu matrix gla protein (MGP) dan bone morphogenetic protein (BMP)-2 terhadap kalsifikasi vaskular pada PGK.

METODE: Penelitian potong lintang ini dilakukan pada 63 subyek yang sedang menjalani perawatan hemodialisis selama lebih dari 3 bulan. Abdominal aortic calcification (AAC) diukur dengan X-ray abdominalis lateral yang ditujukan untuk melihat kalsifikasi pada aorta abdominalis, yang berhubungan dengan derajat deposit kalsifikasi pada segmen vertebra lumbalis (L)1-L4. Kadar serum 8-isoprostane, MGP dan BMP-2 diukur dengan metoda enzyme-linked immunosorbent assay.

HASIL: Penelitian ini menunjukkan kadar 8-isoprostane berkorelasi dengan kadar BMP-2 ( $\mathrm{r}=0,266, p=0,018)$ dan MGP $(\mathrm{r}=0,410, p=<0,001)$. Rasio kadar MGP/BMP-2 berkorelasi dengan skor AAC $(\mathrm{r}=0,279, p=0,013)$. Subyek penelitian dibagi dalam 3 kelompok berdasarkan skor AAC, yaitu: 0, 1-6 dan $\geq 7$. Rerata kadar MGP paling tinggi terdapat pada kelompok skor AAC 1-6, sedangkan rerata kadar 8-isoprostane paling tinggi terdapat pada kelompok skor AAC $\geq 7$. Pada kelompok skor AAC 0, kadar 8-isoprostane berkorelasi dengan kadar MGP $(\mathrm{r}=0,499, p=0,001)$ dan rasio kadar MGP/BMP-2 ( $\mathrm{r}=0,291$, $p=0,034)$. Pada kelompok skor AAC 1-6, 8-isoprostane berkorelasi dengan kadar BMP-2 ( $\mathrm{r}=0,661, p=0,005)$ dan 
$p=0.041$ ). With multivariate logistic regression analyses, we identified that increased MGP/BMP-2 levels ratio (OR: 12.436; 95\%CI: 1.595-96.971) was an independent predictor in aortic calcification event.

CONCLUSION: We concluded that regulators of calcification including calcification inhibitor and promoter related to oxidative stress, were associated with vascular calcification in CKD. MGP levels were increased in the early of calcification and MGP/BMP-2 levels ratio was a strong predictor for vascular calcification in CKD.

KEYWORDS: vascular calcification, CKD, oxidative stress, 8-isoprostane, MGP, BMP-2

Indones Biomed J. 2013; 5(2): 129-36
MGP ( $\mathrm{r}=0,569, p=0,017)$. Pada kelompok skor AAC $\geq 7$, kadar MGP berkorelasi positif dengan skor AAC $(\mathrm{r}=0,608$, $p=0,041)$. Dengan analisis regresi logistik multivariat, kami menemukan bahwa peningkatan rasio kadar MGP/BMP-2 (OR: 12.436; 95\%CI: 1,595-96,971) merupakan prediktor independen pada kejadian kalsifikasi aorta.

KESIMPULAN: Kami menyimpukan bahwa regulator kalsifikasi termasuk inhibitor dan promotor kalsifikasi yang terkait dengan stres oksidatif, berhubungan dengan kejadian kalsifikasi vaskular pada PGK. Kadar MGP meningkat di awal kalsifikasi dan rasio kadar MGP/BMP-2 merupakan prediktor kuat kalsifikasi vaskular pada PGK.

KATA KUNCI: kalsifikasi vaskular, PGK, stres oksidatif, 8-isoprostane, MGP, BMP-2

\section{Introduction}

Chronic kidney disease (CKD) is globally emerging as an important risk factor for morbidity and mortality. Some manifestations of CKD range from proteinuria with normal renal clearance/function to advanced renal failure requiring renal replacement therapy in the form of dialysis or transplantation, commonly called end-stage renal disease (ESRD).(1)

In Indonesia, numbers of CKD patients are rising rapidly. The prevalence of ESRD patients who underwent hemodialysis in 2002 was 1,425 and rised to 3,079 in 2006. The prevalence rates per million populations were 10.2 in 2002 and 23.4 in 2006.(2)

The majority of subjects with CKD are more likely to die of cardiovascular disease (CVD) rather than progress to ESRD requiring renal replacement therapy. Cardiovascular mortality is the leading cause of death in patients treated by dialysis, with mortality 10 to 30 times higher than in the general population despite stratification for gender, race, and presence of diabetes. Patients with CKD have a disproportionate burden of vascular calcification.(1)

Initially it was believed that high phosphate concentrations in CKD caused vascular calcification simply by exceeding the calcium-phosphate solubility products that lead to precipitation, but some later studies have shown that oxidative stress, high phosphate levels, uremic, bone morphogenetic protein (BMP)-2 and high activity level of the phosphate transporter pituitary transcription factor (Pit)-1 induce vascular smooth muscle cell (VSMC) to differentiate from a contractile into an osteoblastic phenotype that behave like osteoblast. Once the osteogenic phenotype is induced, VSMC gains a distinctive molecular fingerprint, marked by the transcription factor core binding factor 1 (Cbfal) that can express alkaline phosphatase (ALP) which synthesize hydroxyapatite crystals. Calcification may occur at several sites in the cardiovascular system, including the intima and media of vessels and cardiac valves. Alternatively, the loss of key mineralization inhibitor such as matrix gla protein (MGP) also contributes to vascular calcification.(3)

Oxidative stress may be a significant contributor to the accelerated pathology associated with ESRD. Diverse mechanisms might account for increased oxidative stress, including antioxidant deficiency, neutrophil activation during dialysis, and chronic inflammation. Oxidative stress reflects an imbalance between the systemic manifestation of reactive oxygen species (ROS) and a biological system's ability to readily detoxify the reactive intermediates such species include free radicals and hydrogen peroxides $\left(\mathrm{H}_{2} \mathrm{O}_{2}\right)$ or to repair the resulting damage. Increased $\mathrm{H}_{2} \mathrm{O}_{2}$ production due to activation of the nicotinamide adenine dinucleotide phosphate (NADPH) oxidase by inflammatory cytokines may activate and translocate nuclear factor kappa-light-chain enhancer of activated B cells (NF- $\kappa \mathrm{B})$ in the endothelial cells. Binding of NF- $\mathrm{KB}$ to its target sequences promotes the expression of BMP-2.(4) 8-isoprostanes plasma has been established as an indicator of in vivo oxidative stress(5) and has been investigated in the pathogenesis of CKD. Research on isoprostanes disclosed much information on increased oxidative stress and related loss of kidney function, in early progression of CKD.(6) 
BMPs are the most potent regulators of osteoblast differentiation among the local factors. They belong to the transforming growth factor (TGF)- $\beta$ superfamily. Cbfal, a member of the runt domain gene family, plays a major role in the processes of determination of osteoblast cell lineage and maturation of osteoblasts. $C b f a 1$ is an essential transcription factor for osteoblast differentiation and bone formation. Binding of BMP to its receptor is an important local factor that up-regulates $C b f a 1$ expression in cells. BMP-2 had profound effects on proliferation, expression of most of the BMPs and the mineralization of human osteoblastic cells.

In atherosclerosis, intimal macrophages and VSMCs express multiple proteins associated with calcification including the vitamin K-dependent protein, MGP.(8) MGP has been identified as a calcification inhibitor in cartilage and vasculature. MGP is able to bind BMP-2 and promote an association between BMP-2 and matrix components. Interaction between MGP and BMP-2 interferes binding of BMP-2 to its receptor and activation of Smad1, part of the BMP signaling system. In vascular calcification, there are contradictory findings regarding the effect of MGP that might depend on its level ratio to BMP-2. On one hand, MGP knockout mice develop profound vascular calcification, whereas on the other hand calcifying atherosclerotic lesions show an increased expression of MGP.(9) Therefore, this study was carried out to investigate the interaction between 8-isoprostane with calcification regulators such as MGP and BMP-2 and the interaction between 8-isoprostane and calcification regulators in vascular calcification in CKD.

\section{Methods}

\section{Study design and Study Subjects}

This study was an observational study with crosssectional design. The study subjects were recruited from haemodialysis centres at several hospitals in Makassar from November 2012 until April 2013. Eligible 63 subjects were enrolled based on inclusion criteria as follows: male or female, aged above 20 years old with CKD stage 5 and duration of haemodialysis more than 3 months. Information on medications, causes of disease, duration of haemodialysis and medical history of diabetes mellitus, hypertension, CVD and others was obtained by interview. Subjects with history of post parathyroidectomy, post kidney transplantation, malignancy, stroke and autoimmune disease were excluded. This study protocol was approved by The Health and Research Ethics Committee, Medical Faculty of Hasanuddin University, Makassar, Indonesia and written informed consent was obtained from each subject.

\section{Blood collection and biochemical analysis}

Blood pressure (BP) was measured by using mercury sphygmomanometer. Blood samples were collected in the morning after overnight fasting and before haemodialysis procedure. Venous blood was drawn using a serum separator tube (SST) and allowed to clot for two hours at room temperature before centrifugation for 20 minutes at approximately $1,000 \mathrm{~g}$. Serum was immediately stored

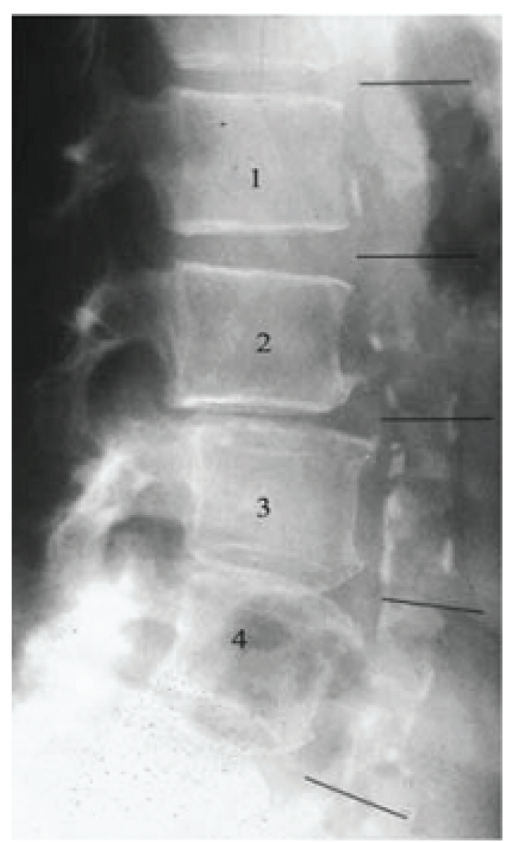

Grading

0 : no calcific deposits in front of the vertebra

1 : small scattered calcific deposits filling less than $1 / 3$ of the longitudinal wall of the aorta

$2: 1 / 3-2 / 3$ of the wall calcified

$3: 2 / 3$ or more of the wall calcified

\begin{tabular}{lcccc}
\hline & & \multicolumn{2}{c}{ Scores for individual segments } & Composite score (AAC) \\
\cline { 3 - 5 } Level & Affected segment & $\begin{array}{c}\text { Posterior wall } \\
\text { Range 0-3 }\end{array}$ & $\begin{array}{c}\text { Anterior wall } \\
\text { Range 0-3 }\end{array}$ & $\begin{array}{c}\text { Anterior-Posterior severity } \\
\text { Range 0-6 }\end{array}$ \\
\hline L1 & 1 & 1 & 0 & 1 \\
L2 & 1 & 2 & 1 & 3 \\
L3 & 1 & 3 & 2 & 5 \\
L4 & 1 & 3 & 3 & 6 \\
Total & 4 & 9 & 6 & 15 \\
Maximum & 4 & 12 & 12 & 24 \\
\hline
\end{tabular}

Figure 1. Abdominal aorta calcification (AAC) scoring.(10) (Adapted with permission from Nature Publishing Group). 
frozen in aliquots at $-20^{\circ} \mathrm{C}$ until assay was done. Blood collection for 8-isoprostane assay was done with special precaution due to instability of the biomarker. The serum was stored frozen with the addition of $0.005 \%$ butylated hydroxytoluene (BHT) to prevent oxidative formation of 8 -isoprostane and also supplemented with indometacin to give a final concentration of at least $10 \mu \mathrm{M}$ to prevent ex vivo formation of eicosanoids. The concentration of 8-isoprostane was measured by competitive enzyme immunoassay (EIA) method using 8-isoprostane EIA kit (Cat. 516351, Cayman Chemical, Ann Arbor, MI). MGP was measured by enzymelinked immunosorbent assay (ELISA) method using human MGP ELISA kit (Cat. E91477Hu, USCN Life Science, Inc., Wuhan, China) and BMP-2 was measured by ELISA method using Quantikine BMP-2 Immunoassay (Cat. DBP200, R\&D systems, Inc., Minneapolis, MN). All assays were carried out at Research \& Esoteric Laboratory of Prodia Clinical Laboratory, Jakarta, Indonesia. The Abdominal Aortic Calcification (AAC) was measured semiquantitively using a lateral abdominal X-ray in which both location and severity of the calcific deposits at each lumbar vertebral segment (L)1-L4. Lateral radiography was performed in the standing position using standard radiographic equipment. A minimum of $4 \mathrm{~cm}$ anterior to the lumbar spines had to be visible: the film distance was $100 \mathrm{~cm}$, other adjustments were: 94KPV, 33-200mAs and the estimated dose of radiation was approximately $15 \mathrm{mGy}$. The calcification of the aorta was graded and scores were calculated using two methods: (a) the composite score for anterior-posterior severity where the scores of individual aortic segments both for the anterior and posterior walls were summed (maximum score 24), and (b) the affected segments score as the total number of aortic segments showing any level of calcification is indicated (maximum score 4). The scoring system is depicted schematically in Figure 1(10).

\section{Data analysis}

Statistical analysis was performed with SPSS for Windows version 17.0 (SPSS Inc., Chicago, IL) for descriptive analysis, Kolmogorov-Smirnov distribution test, MannWhitney test, Spearman correlation and multivariate logistic regression analysis. Hypotheses were tested at a significance level of 0.05 .

\section{Results}

Table 1 showed the characteristics of the subjects (median duration of dialysis 1 (1-9) years; mean age $47.8 \pm 10.9$ years old). Subjects were stratified into 3 groups based on AAC score refer to a previous study(11) as follows: AAC score 0 , $1-6$ and $\geq 7$ groups.

Kolmogorov-Smirnov distribution test showed MGP and ratio MGP/BMP-2 had a normal distribution, while data

Table 1. Baseline characteristic of subjects.

\begin{tabular}{|c|c|c|c|c|c|}
\hline \multirow[b]{2}{*}{ Variable } & \multirow{2}{*}{$\begin{array}{c}\text { Total Samples } \\
\quad(n=63)\end{array}$} & \multicolumn{3}{|c|}{ AAC Score } & \multirow[b]{2}{*}{$p$} \\
\hline & & $\begin{array}{c}0 \\
(n=40)\end{array}$ & $\begin{array}{c}1-6 \\
(n=14)\end{array}$ & $\begin{array}{c}\geq 7 \\
(n=9)\end{array}$ & \\
\hline Gender & & & & & 0.831 \\
\hline Male & $60.3 \%$ & $57.5 \%$ & $64.3 \%$ & $66.7 \%$ & \\
\hline Female & $39.7 \%$ & $42.5 \%$ & $35.7 \%$ & $33.3 \%$ & \\
\hline Age (year) & $47.8 \pm 10.9$ & $43.7 \pm 9.6$ & $53.8 \pm 8.8$ & $56.9 \pm 10.4$ & $0.000 * *$ \\
\hline Duration of HD & & & & & 0.250 \\
\hline$<2$ years & $68.3 \%$ & $67.5 \%$ & $57.1 \%$ & $88.9 \%$ & \\
\hline 2-4 years & $23.8 \%$ & $25.0 \%$ & $28.6 \%$ & $11.1 \%$ & \\
\hline$>4$ years & $7.9 \%$ & $7.5 \%$ & $14.3 \%$ & $0.0 \%$ & \\
\hline BMI $\left(\mathbf{k g} / \mathbf{m}^{2}\right)$ & $22.5 \pm 3.8$ & $22.2 \pm 3.7$ & $23.5 \pm 3.6$ & $22.3 \pm 4.7$ & 0.378 \\
\hline Diabetes Mellitus & $19.0 \%$ & $12.5 \%$ & $28.6 \%$ & $33.3 \%$ & 0.215 \\
\hline SBP (mmHg) & $146.2 \pm 23.2$ & $152.4 \pm 21.3$ & $133.6 \pm 24.0$ & $138.3 \pm 22.1$ & $0.018^{*}$ \\
\hline DBP (mmHg) & $87.3 \pm 15.1$ & $91.3 \pm 13.5$ & $81.4 \pm 17.5$ & $78.3 \pm 12.2$ & $0.005^{* *}$ \\
\hline
\end{tabular}

Mann Whitney test, HD: haemodialysis, BMI: body mass index, SBP: systolic blood pressure, DBP: diastolic blood pressure, * $p \leq 0.05$, $* * p \leq 0.01$. 
Table 2. Biochemical Characteristic of the subjects in each group.

\begin{tabular}{lcccc}
\hline & \multicolumn{5}{c}{ AAC Score } & & $\boldsymbol{p}$ \\
\cline { 2 - 5 } Variable & $\begin{array}{c}\mathbf{0} \\
(\mathbf{n = 4 0})\end{array}$ & $\begin{array}{c}\mathbf{1 - 6} \\
(\mathbf{n = 1 4})\end{array}$ & $\begin{array}{c}\geq 7 \\
(\mathbf{n = 9})\end{array}$ & \\
\hline 8-isoprostane $(\mathrm{pg} / \mathrm{ml})$ & $70.7(17.2-543.4)$ & $58.8(33.5-229.2)$ & $94.1(37.2-543.4)$ & 0.180 \\
BMP-2 (pg/ml) & $34.9(15.9-311.1)$ & $31.8(19.8-86.5)$ & $27.0(19.1-72.2)$ & 0.654 \\
MGP (pg/ml) & $95,509.5 \pm 57,547.1$ & $112,495.2 \pm 46,888.9$ & $98,002.2 \pm 34,749.6$ & 0.585 \\
MGP/BMP-2 & $2,505.7 \pm 1,541.4$ & $3,260.2 \pm 1,487.1$ & $3,126.7 \pm 1,359.6$ & 0.209 \\
\hline
\end{tabular}

Chi-square test, MGP/BMP-2: MGP/BMP-2 levels ratio

Table 3. Correlation of 8-isoprostane, BMP-2, MGP and MGP/BMP-2 levels ratio with AAC score in each group.

\begin{tabular}{|c|c|c|c|c|c|c|c|c|}
\hline \multirow{3}{*}{ Variable } & & & \multicolumn{6}{|c|}{ AAC Score } \\
\hline & \multicolumn{2}{|c|}{$\begin{array}{l}\text { Total Samples } \\
\qquad(n=63)\end{array}$} & \multicolumn{2}{|c|}{$\begin{array}{c}0 \\
(n=40)\end{array}$} & \multicolumn{2}{|c|}{$\begin{array}{c}1-6 \\
(n=14)\end{array}$} & \multicolumn{2}{|c|}{$\begin{array}{c}\geq 7 \\
(n=9)\end{array}$} \\
\hline & $\mathbf{r}$ & $p$ & $\mathbf{r}$ & $p$ & $\mathbf{r}$ & $p$ & $\mathbf{r}$ & $p$ \\
\hline 8-isoprostane (pg/ml) & 0.150 & 0.121 & - & - & 0.030 & 0.460 & -0.077 & 0.422 \\
\hline BMP-2 (pg/ml) & -0.127 & 0.160 & - & - & -0.238 & 0.207 & -0.110 & 0.389 \\
\hline MGP (pg/ml) & 0.151 & 0.118 & - & - & -0.207 & 0.238 & 0.608 & $0.041 *$ \\
\hline MGP/BMP-2 ratio & 0.279 & $0.013 *$ & - & - & 0.074 & 0.401 & 0.287 & 0.227 \\
\hline
\end{tabular}

Spearman correlation test, MGP/BMP-2: MGP/BMP-2 levels ratio

Table 4. Correlation of 8-isoprostane with MGP, BMP-2 and MGP/BMP-2 levels ratio in each group.

\begin{tabular}{|c|c|c|c|c|c|c|c|c|}
\hline \multirow{4}{*}{ Variable } & \multicolumn{8}{|c|}{ 8-isoprostane (pg/ml) } \\
\hline & \multirow{2}{*}{\multicolumn{2}{|c|}{$\begin{array}{l}\text { Total Samples } \\
\qquad(n=63)\end{array}$}} & \multicolumn{6}{|c|}{ AAC Score } \\
\hline & & & \multicolumn{2}{|c|}{$\begin{array}{c}0 \\
(n=40)\end{array}$} & \multicolumn{2}{|c|}{$\begin{array}{c}1-6 \\
(n=14)\end{array}$} & \multicolumn{2}{|c|}{$\begin{array}{c}\geq 7 \\
(n=9)\end{array}$} \\
\hline & $r$ & $p$ & $r$ & $p$ & $r$ & $p$ & $r$ & $p$ \\
\hline BMP-2 (pg/ml) & 0.266 & $0.018^{*}$ & 0.146 & 0.185 & 0.661 & $0.005^{* *}$ & 0.339 & 0.186 \\
\hline MGP (pg/ml) & 0.410 & $0.000 * *$ & 0.499 & $0.001 * *$ & 0.569 & $0.017^{*}$ & -0.203 & 0.300 \\
\hline MGP/BMP-2 & 0.096 & 0.227 & 0.291 & $0.034^{*}$ & -0.147 & 0.308 & -0.390 & 0.150 \\
\hline
\end{tabular}

Spearman correlation test, MGP/BMP-2: MGP/BMP-2 levels ratio, ${ }^{*} p \leq 0.05$, ${ }^{*} p \leq 0.01$

Table 5. Univariate and multivariate logistic regression analysis

\begin{tabular}{lccccccc}
\hline \multirow{2}{*}{ Variable } & \multicolumn{3}{c}{ Univariate Analysis } & \multicolumn{3}{c}{ Multivariate Analysis } \\
\cline { 2 - 7 } & OR & $\mathbf{9 5 \%}$ CI & $\boldsymbol{p}$ & OR & $\mathbf{9 5 \%}$ CI & $\boldsymbol{p}$ \\
\hline 8-isoprostane $(\mathrm{pg} / \mathrm{ml})$ & 1.476 & $0.527-4.137$ & 0.459 & 1.683 & $0.303-9.355$ & 0.552 \\
BMP-2 (pg/ml) & 0.696 & $0.248-1.953$ & 0.491 & 1.148 & $0.212-6.225$ & 0.873 \\
MGP (pg/ml) & 1.589 & $0.565-4.465$ & 0.380 & 0.649 & $0.103-4.081$ & 0.645 \\
MGP/BMP-2 & 3.231 & $1.111-9.393$ & 0.031 & 12.436 & $1.595-96.971$ & 0.016 \\
\hline
\end{tabular}

Logistic regression analysis, MGP/BMP-2: MGP/BMP-2 levels ratio, OR: odds ratio, CI: confidence interval 
of 8-isoprostane, BMP-2 and score AAC had an abnormal distribution, thus non parametric tests were used for data analysis (data not shown).

Table 2 shows the biochemical characteristics of subjects that were stratified into 3 groups. Although no statistically significant differences were noted for all variables among groups, we found that concentrations of MGP and MGP/BMP-2 levels ratio were higher in AAC score 1-6 group than in AAC score 0 and $\geq 7$ groups.

Age, duration of haemodialysis and acute inflammation status were independent risk factors that could be affected on the research variables. However, the Spearman correlation test showed that there was no correlation of those risk factors with all variables, except correlation between acute inflammation status represented by high-sensitivity C-reactive protein (hsCRP) and 8-isoprostane levels (data not shown).

Table 3 shows significant correlation between AAC score and MGP/BMP-2 levels ratio in the total samples $(\mathrm{r}=0.279, p=0.013)$, and also with MGP in AAC score $\geq 7$ group $(\mathrm{r}=0.608, p=0.041)$.

Spearman correlation test (Table 4) showed significant correlation between 8-isoprostane and BMP-2 in the total samples $(\mathrm{r}=0.266, p=0.018)$ and in AAC score 1-6 group $(\mathrm{r}=0.661, p=0.005)$. There were also significant correlation between 8-isoprostane and MGP in the total samples $(\mathrm{r}=0.410, p \leq 0.001)$, in $0(\mathrm{r}=0.499, p=0.001)$ and in AAC score 1-6 groups ( $\mathrm{r}=0.569, p=0.017)$.

Univariate and multivariate logistic regression analyses (Table 5) showed that MGP/BMP-2 levels ratio (OR: 12.4; 95\% CI: 1.595-96.971, $p=0.016$ ) was a strong predictor for the occurance of vascular calcification in CKD.

\section{Discussion}

Vascular calcification is a form of ectopic mineralization which arises from deposition of calcium and phosphate in major arteries and cardiac valves. The incidence of vascular calcification is positively correlated with high mortality and morbidity rate for CVD, this is due to the formation of hydroxyapatite crystals in the distinct layers of blood vessels that is responsible for increased stiffness and decreased compliance of arterial walls. The most severe form of calcific vasculopathy is medial calcification that is observed in ESRD which occurs in the tunica media, the layer that supplies mechanical strength and contractile power. It is a necrotizing condition triggered by the exposure to increased oxidative stress and a condition with inflammation that are characteristic of the uremic milieu and negatively affect the endothelial function. In the past vascular calcification was thought to be an entirely "passive" process and this meant that any therapeutic strategy would not have been able to reverse or, at least, slow it down. Recent studies have pointed out that ectopic calcification instead is a highly regulated cell-mediated process which shares many similarities with the physiological mineralization in the bone. The key cellular effectors of mineralization within the vascular wall are the osteoblast-like cells derived from VSMCs differentiation. In transformed VSMCs, several osteoblast-specific genes become activated, and the cells acquire the ability to synthesize bone-specific extracellular matrix, to accumulate bone-specific minerals, and to form bone-specific tridimensional structures or hydroxyapatite crystals.(12) Several stimuli induce VSMCs to undergo osteogenic differentiation, including oxidative stress, BMPs or changes in pyrophosphate levels.(3)

Plasma 8-isoprostanes as an in vivo oxidative stress is derived from oxidative modification of arachidonic acid. Previous studies showed patients on long-term haemodialysis might be under increased oxidative stress caused by either haemodialysis or renal failure.(5) The previous studies demonstrated oxidative stress enhanced differentiation of calcifying vascular cells and inhibited differentiation of bone cells.(13) Other studies also showed a strong relationship between concentrations of circulating F2-isoprostanes and the early development of coronary artery disease as measured by coronary artery calcium (CAC).(14) In our study, we examined weak positive correlation between 8-isoprostane level and AAC score $(\mathrm{r}=0.150, p=0.121)$, which could be explained that there were many other risk factors instead of oxidative stress that could also have affected the severity of calcification in CKD, including age, duration of haemodialysis, diabetes mellitus and hypertension. However, we found a positive correlation between 8-isoprostane with BMP-2 ( $\mathrm{r}=0.266, p \leq 0.05)$ and MGP levels $(0.410, p \leq 0.001)$ in all total subjects. In the subject group with early calcification (AAC score 1-6), but not in the group with extended calcification (AAC score $\geq 7$ ), it also showed a positive correlation between 8-isoprostane with BMP-2 ( $\mathrm{r}=0.661, p \leq 0.01)$ and MGP levels $(\mathrm{r}=0.569$, $p \leq 0.05$ ). This latter finding may also explain that the role of oxidative stress in calcification occurs via promoting the expression of mineralization regulators including MGP and BMP-2, and enhancing differentiation of VSMC to become an osteoblastic phenotype.

Artery wall calcification associated with atherosclerosis frequently contains fully formed bone tissue including marrow. BMP-2 a potent factor for osteoblastic 
differentiation was found to be expressed in calcified human atherosclerotic plaque.(15) BMP-2 secretion is progressively increased in bovine VSMCs during mineralization and uremic serum enhances its secretion. It is likely that both Cbfal and BMP-2 may be more critical in the initiation of osteoblast-like cell phenotypic change of uremic-serumtreated bovine VSMCs, but thereafter, other factors are also important in the continuation of the calcification.(16)

MGP is an extracellular matrix protein with wide tissue distribution detectable in the normal blood and in calcified atherosclerotic plaques. Its main sources are cartilage and the vessel wall where it is synthesized by chondrocytes and VSMCs, respectively. Its function is to inhibit medial calcification of arteries and thereby to protect the normal environment in the vascular wall.(17) The mechanisms remain unclear. At least two mechanisms could account for those mechanisms, first, MGP binds calcium ions and hydroxyapatite via its five $\gamma$-carboxylated glutamic acid (Gla) residues, second, MGP has been shown to modulate the biological activity of the TGF- $\beta$ superfamily members such as BMPs.(18)

in vitro study conducted by Zebboudj, et al., showed MGP has been demonstrated to exert dose-dependent inhibitory effect on osteoblastic differentiation through interference with binding of BMP-2 to its receptor. It provided evidence that MGP is a regulatory protein for BMP-2. MGP has a dose-dependent effect on BMP-2 induced osteoblastic differentiation in M2 cells. Relative low levels of MGP to BMP-2 (less than 1-fold) result in mild enhancement of BMP-2 activity. Intermediate levels $(\sim 1-15$-fold) result in inhibition and high levels (above 15 fold) result in strong enhancement of BMP-2 activity. When the levels of MGP exceeded 12-15-fold relative to BMP-2, there would be a trend of increased osteoinduction in ALP assay and decreased binding of BMP-2 to whole cells and matrix. In large excesses of MGP (20-80-fold) relative to BMP-2, there is a strong enhancement of the osteoinductive effect of BMP-2 and a corresponding activation of Smad1. One possible explanation for this phenomenon may be saturation of association sites.(9)

However, other studies have shown MGP significantly increased in patients with severe atherosclerosis. Higher MGP could therefore be a positive indicator for the prognosis due to its function as an inhibitor of medial calcification of arteries and may indicate progressing media and intima calcification processes. Moreover, these processes were paralleled by increased inflammation, which may reflect an initial event very early in the process that leads to calcification.(17) A study conducted by Proudfoot, et al., also showed VSMCs in calcifying cells expressed high levels of MGP mRNA. It is possible MGP becomes immobilized in the nodular calcifying cells and is unable to clear calcium into the external medium. The increase in MGP mRNA in the nodular cells may be due to the cells' detection of an accumulation of calcium and a feedback mechanism for production of additional MGP.(19)

Our study results showed the mean of MGP was higher in AAC score 1-6 group than in the other groups, although statistically not significant, it might indicate that calcification process in the media and intima was accelerated due to its function as an inhibitor of medial calcification of arteries at the early phase of calcification. There was significant correlation between AAC score and MGP/BMP2 levels ratio in the total CKD samples $(\mathrm{r}=0.279, p=0.013)$ and with MGP in AAC score $\geq 7$ group ( $\mathrm{r}=0.608, p=<0.05$ ). Univariate and multivariate analyses in our study also showed that MGP/BMP-2 levels ratio (OR: 12.4 , 95\%CI: 1.595-96.971, $p=0.016$ ) was a strong predictor for vascular calcification events.

Overall results of this study suggested that 8 -isoprostane as an oxidative stress may be one of the contributors to the accelerated vascular calcification events associated with CKD via enhancing osteogenic regulator both inhibitor and promoter calcification. The highest mean of MGP level at the AAC score 1-6 group may indicate as a feedback mechanism of cells to produce additional MGP to clean up excessive calcium and also indicate that media and intima calcification still progresses in the early phase of calcification. Positive correlation between MGP/ BMP-2 levels ratio with severity of calcification suggested that increased levels of MGP exceeding relative to BMP2 indicate larger excess of MGP relative to BMP-2, the stronger enhancement of the osteoinductive effect of BMP2 which could also induce differentiation of VSMC to an osteoblastic phenotype.

Vascular calcification in this study was determined as AAC measured using a lateral abdominal X-ray as described by Honkanen, et al., and Belassi, et al.(10,11) The X-ray was less sensitive than Computed Tomography (CT)-based technique, hence it is one of the limitations of this study. Further studies using more sensitive technique to assess vascular calcification and involving more eligible number of samples are required to provide more valuable information about relationships between oxidative stress and osteogenic regulator with vascular calcification in CKD. This approach might prove to be a useful tool that would compliment strategy in pharmacologic therapy of vascular calcification in $\mathrm{CKD}$. 


\section{Conclusion}

We concluded that regulators of calcification including inhibitor and promoter of calcification related to oxidative stress are associated with vascular calcification in CKD. We found that MGP level increased in the early phase of calcification and MGP/BMP-2 levels ratio was a strong predictor for vascular calcification in CKD.

\section{Acknowledgement}

We thank to the Prodia Education and Research Institute for funding this research.

\section{References}

1. Moe SM, Chen NX. Pathophysiology of Vascular Calcification in Chronic Kidney Disease. Circ Res. 2004; 95: 560-7.

2. Prodjosudjadi W, Suhardjono A. End-Stage Renal Disease In Indonesia: Treatment Development. Ethn Dis. 2009; 19[Suppl 1]: S1-33-6.

3. Johnson RC, Leopold JA, Loscalzo J. Vascular Calcification: Pathobiological Mechanisms and Clinical Implications. Circ Res. 2006; 99: 1044-59.

4. Csiszar A, Lehoux S, Ungvari Z. Hemodynamic Forces, Vascular Oxidative Stress and Regulation of BMP-2/4 Expression. Antioxid Redox Signal. 2009; 11: 1683-97.

5. Handelman GJ, Walter MF, Adhikarla R, Gross J, Dallal GE, Levin $\mathrm{NW}$, et al. Elevated plasma F2-isoprostanes in patients on long-term hemodialysis. Kidney Int. 2001; 59: 1960-6.

6. Small DM, Coombes JS, Bennett N, Johnson DW, Gobe GC. Oxidative stress, anti-oxidant therapies and chronic kidney disease. Nephrology (Carlton). 2012; 17: 311-21.

7. Yamaguchi A, Komori T, Suda T. Regulation of Osteoblast Differentiation Mediated by Bone Morphogenetic Proteins, Hedgehogs, and Cbfa1. Endocr Rev. 2000; 21: 393-411.

8. O'Donnell CJ, Shea MK, Price PA, Gagnon DR, Wilson PWF, Larson MG, et al. Matrix Gla Protein is Associated with Risk Factors for Atherosclerosis but not with Coronary Artery Calcification. Arterioscler Thromb Vasc Biol. 2006; 26: 2769-74.

9. Zebboudj AF, Imura M, Boström K. Matrix GLA Protein, a Regulatory Protein for Bone Morphogenetic Protein-2. J Biol Chem. 2002; 277: 4388-94

10. Honkanen E, Kauppila L, Wikström B, Rensma PL, Krzesinski JM, Aasarod K, et al. Abdominal aortic calcification in dialysis patients: results of the CORD study. Nephrol Dial Transplant. 2008; 23: 4009-15.

11. Bellasi A, Ferramosca E, Muntner P, Ratti C, Wildman RP, Block GA, et al. Correlation of simple imaging tests and coronary artery calcium measured by computed tomography in hemodialysis patients. Kidney Int. 2006; 70: 1623-8.

12. Stompór T. An Overview of the Pathophysiology of Vascular Calcification in Chronic Kidney Disease. Perit Dial Int. 2007; 27 Suppl 2: S215-22.

13. Mody N, Parhami F, Safarian TA, Demer LL. Oxidative Stress Modulates Osteoblastic Differentiation of Vascular and Bone Cells.
Free Radic Biol Med. 2001; 31: 509-19.

14. Gross M, Steffes M, Jacobs DR Jr, Yu X, Lewis L, Lewis CE, et al. Plasma F2-isoprostanes and Coronary Artery Calcification: The CARDIA Study. Clin Chem. 2005; 51: 125-31.

15. Boström K, Watson KE, Horn S, Wortham C, Herman M, Demer LL. Bone Morphogenetic Protein Expression in Human Atherosclerotic Lesions. J Clin Invest. 1993; 91: 1800-9.

16. Chen NX, Duan D, O’Neill KD, Wolisi GO, Koczman JJ, Laclair R, et al. The mechanisms of uremic serum-induced expression of bone matrix proteins in bovine vascular smooth muscle cells. Kidney Int. 2006; 70: 1046-53.

17. Thomsen SB, Rathcke CN, Zerahn B, Vestergaard H. Increased levels of the calcification marker Matrix Gla Protein and the inflammatory markers YKL-40 and CRP in patients with type 2 diabetes and ischemic heart disease. Cardiovasc Diabetol. 2010; 9: 86.

18. Price PA, Faus SA, Williamson MK. Warfarin Causes Rapid Calcification of the Elastic Lamellae in Rat Arteries and Heart Valves. Arterioscler Thromb Vasc Biol. 1998; 18: 1400-7.

19. Proudfoot D, Skepper JN, Shanahan CM, Weissberg PL. Calcification of Human Vascular Cells In Vitro Is Correlated With High Levels of Matrix Gla Protein and Low Levels of Osteopontin Expression. Arterioscler Thromb Vasc Biol. 1998; 18: 379-88. 